\title{
Die begrafnisdiens
}

\author{
MJ du P Beukes \\ Universiteit van Pretoria
}

\begin{abstract}
The burial service

The goal of this study is to indicate that the burialservice is not only the concern of the family, but also that of the church - it is a church-family concern. Biblical and historical data for the greater part confirm this statement. The Church Reformers considered the burial service in principal as a church matter. From the point of view that the burial service is a church-family matter, the church has the responsibility to define the burial service in respect of practical-theological guidelines whilst also taking the needs of the family into consideration.
\end{abstract}

\section{PROBLEEMSTELLING}

Die kerk is voortdurend besig om mense te begrawe. Dit is ' $n$ moderne tendens om die klem al hoe meer op die mens en sy behoeftes te lê. Sekere beoefenaars van die liturgiek oordeel dat die kerk in sy besinning oor die kerklike praktyk in die eerste plek na die mens en sy behoeftes moet vra. Die mens en sy behoeftes is volgens hulle die bepalende. Ook wat die begrafnisdiens betref, is die aandrang al hoe sterker by veral sekere lidmate van die kerk dat die familie en die vriende in alle opsigte die bepalende behoort te wees - hulle wense moet geheel en al eerbiedig word. Dit bring noodwendig mee dat die begrafnisdiens gedegradeer word tot ' $n$ suiwer sosiale aangeleentheid.

In hierdie proses word die preek met 'n stigtelike praatjie vervang. Die kerklik-goedgekeurde lied word deur allerlei sentimentele sang verdring. Tydens die begrafnisdiens gaan dit dan dikwels meer om die gestorwene as om die verkondiging van Jesus Christus. Dit word belangriker om die gestorwene se familie met kos te versorg as met die evangelie van Jesus Christus. Hierdie antropologiese 
benadering word gestimuleer as die begrafnis as 'n familie-aangeleentheid beskou word (Pont 1984: 111-122).

Teenoor bogenoemde benadering word die begrafnis suiwer as 'n aangeleentheid van die kerk beskryf. Die kerklike word so oorbeklemtoon dat die indruk gelaat word dat die begrafnisdiens en al sy uitlopers net so in die Bybel voorgeskryf word. Die kerklike word so oorbeklemtoon dat daar hoegenaamd geen plek vir die familie en hulle behoeftes is nie. Hier is die prediking Christosentries, maar is nie gerig om die treurendes in hulle konkrete situasie te troos nie. Die prediking is so algemeen van aard dat elke begrafnispreek weer vir 'n volgende begrafniserediens gebruik kan word. Die agtergeblewenes word deeglik met die evangelie versorg, maar die gemeente dink nie daaraan dat hier ook 'n behoefte met betrekking tot materiële versorging bestaan nie.

Met die oog op 'n prinsipiële verantwoorde praktyk sal die kerk 'n antwoord moet vind op die vraag of die begrafnis ' $n$ suiwer kerklike of ' $n$ suiwer familieaangeleentheid is of miskien 'n kombinasie van beide.

\section{METODE VAN AANPAK}

In hierdie studie gaan ons die metode volg wat deur Hoenderdaal (1977: 33) beskryf word as die Bybels-historiese en antropologiese metode.

Dit beteken in praktyk dat ons gaan vra wat se die Bybel en die geskiedenis ten opsigte van ons tema, en hoe kan ons dit vir die gelowige van hier en nou relevant maak. Uit die aard van die saak sal nie net die gegewens wat reeds geskiedenis geword het, hanteer word nie, maar ook die jongste gegewens wat oor ons tema beskikbaar is.

Die Praktiese Teologie wil aityd die teorie na die praktyk deurtrek. Dit bring noodwendig mee dat ons, nadat ons antwoord op ons vraag gevind het, ook sal probeer antwoord gee oor die wyse waarop die begrafnisdiens in praktyk in die kerk behoort te funksioneer.

\section{BYBEL S - DOGMATIESE GEGEWENS}

Uitgebreide Bybelse gegewens oor mense se dood en hulle begrafnis is baie skaars. In die meeste gevalle sê die Bybel net dat iemand dood is en begrawe is (kyk o a Num 20: 1; Jos 24: 30; Hand 5: 5 - 11). Selfs van die bekende koning Salomo se dood word net gese: 'Hy is oorlede, en hy is begrawe by sy pa in die Dawidstad' (1 Kon 11: 42). 
Gebruike rondom die begrafnis het van geslag tot geslag gewissel. De Vaux noem die volgende as algemene begrafnisgebruike by Israel: Die begrafnis het gewoonlik op dieselfde dag as die sterwe plaasgevind. Die oorledene is in doeke toegedraai en saam met sy familie in 'n grot begrawe, asook met 'n deel van sy besittings. Voor die begrafnis het die familie gerou. Die routydperk het gewissel (De Vaux 1961: 108).

Was die begrafnis ' $n$ familie of ' $n$ kerklike aangeleentheid? Hierdie vraag word nie in die Bybel beantwoord nie. Abraham het sy vrou begrawe (Gen 23: 1920). Isak en Ismael het vir Abraham begrawe (Gen 25: 9). Jakob is deur Josef, sy hele familie en al die amptenare van Egipte begrawe (Gen 50: 7). Jerobeam se kind is begrawe en die hele Israel het oor hom rou bedryf (1 Kon 14: 18). Hoewel dit algemene gebruik was dat die familie die dooie begrawe het (De Vaux 1961: 108), sien ons uit bostaande gegewens dat dit soms gebeur het dat selfs die hele volk Israel en in enkele gevalle selfs ander volke by die begrafnis betrokke was (Gen 50: 7; 1 Sam 31: 13).

Hoedanig was die kerk se betrokkenheid volgens die Bybel by 'n begrafnis? Die Bybel sê niks daarvan nie. Dit is egter belangrik om daarop te let dat hulle in die tyd van die aartsvaders self die kerk was. Later het die grense van kerk en volk saamgeval. As die Bybel dus sê Abraham het sy vrou begrawe kan net so wel gesê word dat die kerk van daardie tyd Abraham se vrou begrawe het. As die volk treur oor Jerobeam se kind wat dood is, is dit daarom ook in werklikheid die kerk van daardie tyd wat oor die dood treur.

Die 1977-Diensboek van die Nederduitsch Hervormde Kerk van Afrika beskryf die begrafnisdiens in die kerk as 'n kerklike aangeleentheid, maar die diens by die graf as ' $n$ familie-aangeleentheid. Die teraardebestelling, sê die Diensboek (1977:31), 'word in die Bybel duidelik geteken as taak en voorreg van die familie' (Gen 23: 6, 11, 15; 47: 29; Matt 8: 21; 27: 57-61; Joh 11:34). Hierdie onderskeid wat die Diensboek maak, is egter geforseerd. By die reeds genoemde argument kan die volgende gevoeg word. Nie een van hierdie tekste gee opdrag dat die teraardebestelling deur die familie moet plaasvind nie. Die Skrif gee in hierdie verband geen vaste voorskrifte nie. Die Skrif maak slegs melding van die feit dat mense gesterf het, en begrawe is. Uit die feit dat die familie hierdie mense begrawe het, word soms die afleiding gemaak dat die begrafnis 'n suiwer familie-aangeleentheid was. Hierdie is 'n verkeerde gebruik van die Skrif. As die Skrif in sy verhalende gedeeltes 'n bepaale saak vermeld, beteken dit tog nie dat ons hier te doen het met 'n geldende voorskrif vir alle gelowiges van alle tye nie! Die feit dat die familie die ontslapenes begrawe het, is 'n doodnatuurlike verskynsel wat op daardie stadium gegeld het en vir altyd so sal wees en behoort te wees. 
Net soos die Ou Testament is die Nuwe Testament se gegewens oor die begrafnis baie skaars. Die Nuwe Testament beskryf nie begrafnisgebruike nie, maar verkondig wat met die dood gebeur het deur Jesus Christus se oorwinning oor die dood: graf en dood is oorwin en God en mens is versoen (kyk veral Rom 7: 12-21; 1 Kor 15).

Of die begrafnis die taak van die kerk of die familie is, sal miskien gevra moet word aan die hand van die vraag: wat is die kerk se roeping in die wêreld? Die kerk se opdrag is om Jesus Christus te verkondig (Matt 28: 19; Hand 1: 9; 2 Tim 4: 2). Die Heidelbergse Kategismus beskryf die kerk as die besondere gestalte waarbinne God met sy Gees en Woord sy eiendom vergader, beskerm en onderhou (Heidelbergse Kategismus Vraag en antwoord 54).

Hierdie versorging van die Heilige Gees deur Woord en Gees geskied in die besonder deur die verkondiging van die Woord en die bediening van die sakramente (Heidelbergse Kategismus, Vraag en antwoord 65). Deur hierdie bediening kry mense deel aan Christus en al sy weldade en word hulle getroos en bemoedig (Heidelbergse Kategismus, Vraag en antwoord 53).

Die bedienaar van die Woord het die roeping om op 'n besondere wyse die roeping van die kerk in sy bediening uit te leef. Volgens die formulier vir die bevestiging van die dienaars van die Goddelike Woord moet hy die Woord verkondig, die gemeente in gebed voorgaan, die sakramente bedien en goeie dissipline in die gemeente handhaaf. Die verkondiging moet oor die algemeen en in die besonder geskied deur die hoorders 'te onderrig, te vermaan, te vertroos en te bestraf, soos dit in elke geval nodig is' (Diensboek 1987: 83).

Die Bybelse opdrag aan die kerk om die evangelie van Christus te verkondig, word op verskillende wyses gedoen. Die kerk doen dit deur die prediking, die pastoraat, die kategese, die evangelisasie en die sending. Al hierdie verkondigingsgestaltes het sekere sake in gemeen. Besondere karakteristieke, veral ten opsigte van die mense tot wie dit gerig is, bring die besondere van elke verkondigingsgestalte na vore. Uit die Skrif is dit duidelik, soos dit ook verwoord is in die bevestigingsformulier van predikante, dat hierdie verkondiging gerig is tot die gemeente, maar ook tot die mens in die konkrete situasie waarin hy hom bevind. Hierdie verkondiging is daarom soms meer lerend en soms meer vertroostend; soms gerig tot die hele gemeente soms gerig tot enkelinge of enkele families. As dit nou gebeur dat 'n familie van die gemeente, of 'n mens wat op die pad van die kerk kom, in die allergrootste ellende gedompel word deur die dood, dan het die kerk ten opsigte van hierdie mense 'n besondere taak. Hierdie taak sal in die eerste plek wees om die Woord aan hulle te verkondig en andersyds om op 'n besondere wyse barmhartigheidsdiens aan hulle te bewys. 
Kragtens die roeping wat die kerk ontvang het, en in die lig van die besondere nood wat mense tydens die dood beleef, sal die kerk nie anders kan as om by die begrafnis van sy lidmate betrokke te wees nie.

\section{HISTORIESE GEGEWENS}

\subsection{Die vroeē Christelike kerk}

'Uit die kerkgeskiedenis blyk dit dat die vroeë Christelike Kerk die begrafnis beskou het as 'n kerklike aangeleentheid' (Barnard 1976: 76). Die begrafnisdiens is as deel van die gemeente se Christelike plig gesien. Hoewel daar nie gepreek is nie, het ander elemente van die erediens soos gebed en sang wel voorgekom (Wagenaar 1964: 52). Op 'n baie vroeë staduim in die die kerkgeskiedenis het daar vir begrafnisse 'n uitgebreide optrede bestaan. Sommige van hierdie momente toon sterk liturgiese trekke:

(a) Prayer in the house - the corpse was washed and anointed and swathed in white linen to the accompaniment of prayers. (b) Procession - whereas the Romans chose night for interment because of a belief that a funeral was of evil omen, the Christians chose the daytime, and, wearing white garments, sang psalms of hope and alleluias of victory. Palm leaves were carried, together with lights, and incense was burned - all expression. (c) Office - a short service of praise and thanksgiving, around the body, including Bible readings and psalms. (d) Eucharist - the celebration expressed the belief in the communion that still exists between the living and the dead. The kiss of peace (q.v.) was given to the corpse. (e) Interment - the corpse was placed in the grave with the feet towards the east as a sign of hope in the coming of the Sun of Righteousness (Davies 1972: 96-97).

$\mathrm{Na}$ die diens het daar gewoonlik 'n liefdesmaal plaasgevind. Op die derde, negende en veertiende dag na die begrafnis het die familie en vriende weer vir gebede en sang saamgekom. Die optrede tydens die begrafnisdiens was nie stereotiep nie. Dit het, afhangende of die diens direk uit die huis of uit die kerk plaasgevind het, gewissel. Die begrafnisdiens is gekenmerk deur die oortuiging dat Jesus Christus die dood oorwin het. 


\subsection{Die Oos-Ortodokse kerk}

Die begrafnis is in die Oos-Ortodokse kerke in die vierde eeu as 'n kerklike aangeleentheid gehanteer. Die lyk is in die kis geplaas met sy gesig na die altaar. Die kis is oopgemaak sodat die anwesiges die volle realiteit van die dood kon beleef. Die oorwinning oor die dood deur Jesus Christus was egter die middelpunt en die oorheersende gedagte van die seremonie. Die liturgie vir die begrafnisdiens het in 'n groot mate ooreengestem met dié van die Sondagerediens. Net soos die Sondagerediens was die begrafnisdiens ook 'n herdenking van Christus se oorwinning oor die dood. Veral gebed en sang het 'n belangrike plek tydens hierdie erediens ingeneem (Rowell 1979: 19).

\subsection{Roomse-Katolieke Kerk}

In die vroeë Middeleeue het die begrafnis uit die voorbereiding van die liggaam bestaan. Die voorbereiding is met die sing van psalms en gebede vergesel. Hierna het die prosessie met die lyk van die huis na die kerk gevolg. Hierna het die stoet na die begrafplaas beweeg en het die teraardebestelling plaasgevind. Later het die voorbereiding van die lyk 'n private aangeleentheid geword (Davies 1972: 99).

Die nagmaal het geleidelik 'n normale deel van die begrafnisdiens geword en al hoe meer on-Bybelse seremonies het deel van die begrafnisdiens geword. Kruise en relikwiee is voor die begrafnisoptog gedra. Die kis is met wywater besprenkel. Die priester het allerlei kruisetekens bokant die kis gemaak. Die dodemis het geleidelik uit die nagmaalsviering ontwikkel (Barnard 1976: 76).

In 1614 is die Rituale Romanum aanvaar. Dit was die eerste amptelike begrafnisseremonie wat voorgeskryf is om algemeen is die Rooms-Katolieke Kerk gebruik te word. Dit begin met die optog wat onder psalmgesing die ligaam van die huis na die kerk vervoer. Die liggaam word in die kerk ontvang. Hierna is die liggaam onder gesang na die begraafplaas geneem en na 'n gebed is dit begrawe. Die lied wat gesing is, is die In paradisum ... chorus angelorum. In die lied word die dooie in die paradys verwelkom en die opstanding van die liggaam geprys (Davies 1972: 98).

Allerlei bygelowe het veral in die Middeleeue ontstaan. Hierdie bygeloof is deur die kerk toegelaat. Die vrees het bestaan dat allerlei bose geeste die oorledene kan skade aandoen. Hierdie bose geeste moes met klokgelui verskrik word. Om te verhinder dat die dooie na die huis sou terugkom om te spook, moet die begrafnisstoet voor en na die begrafnis 'n aantal kere om die begraafplaas beweeg. Om veral die familie onkenbaar te mak vir die dooie moes hulle na die dood ander klere as gewoonlik dra (Die ou Germane het bv wit vir besondere 


\section{Begrafnisdiens}

rouklere gebruik. Sedert 1498, na die dood van Karel VII, is wit met swart vervang.) Grond of ander voorwerpe is op die graf gegooi om die siel van die dooie sogenaamd in die graf te hou (Wagenaar 1964: 20-22).

$\mathrm{Na}$ ' $\mathrm{n}$ baie deeglike studie van die begrafnis by die Rooms-Katolieke in die Middeleeue konkludeer Wagenaar (1964: 52) soos volg:

In de Oude Kerk was de begrafenis een zaak van de gemeente. Er werd bij het graf gebeden en er werden liederen gezongen, die de overwinning van de Heer over de dood, en de hoop van de opstanding vertolken. Gepreekt werd er niet. Wel kwam in latere tijd de gedachtenisrede voor bij de dood van hooggeplaatste personen. In de R-K Kerk zien wij de begrafenis zich ontwikkelen tot een speciale dienste voor de dode en zijn lot, dat, naar men meende, door de Kerk nog beïnvloed kon worden. Vergeleken bij deze zielemis heeft de ceremonie bij het graf slechts geringe betekenis. De eventuele grafrede is onbelangrijk, en meer gedachtenisrede dan woordverkondiging.

Die Tweede Vatikaanse Konsilie van die Rooms-Katolieke Kerk het met sy liturgiese konstitusie Ordo Exequiarum in 1969 'n groot variasie van begrafnisdienste toegelaat. Die rites is baie buigbaar en laat vryheid vir plaaslike gebruike. Groot klem word op die 'Paschal character of Christian death' gelê (Davies 1972: 99). Drie diensvorme word nou toegelaat: Die tradisionele een wat plaasvind by die huis, die kerk en die graf. Een wat plaasvind by die kapel en die graf en een soos in Afrika slegs by die huis en die graf (Davies 1972: 99). Die nagmaal is nie meer noodsaaklik by die begrafnis nie. Die vryspraak is verander in 'n finale afskeid van die dooie. 'n Baie wye keuse vir gebede en sang word toegelaat. 'n Gebed vir die treurendes is ook ingevoer. 'The whole rite expresses Christian hope in our share in Christ's resurrection and enjoyment of God's presence in his kingdom' (Davies 1972: 99).

\subsection{Kerkhervormers}

\subsubsection{Luther}

Luther het skerp teen die mis vir dooies en al die gebruike van die RoomsKatolieke Kerk met betrekking tot die begrafnis te velde getrek. 
Hierdie radikale verwerping van die Roomse gebruike het daartoe gelei dat Kerkhervormers vir 'n baie lang tyd die begrafnis geheel en al in die hande van die familie en die owerhede gelaat het. Luther het breë voorskrifte vir die doop en die huwelik opgestel, maar niks vir die begrafnis nie. Prinsipieel het Luther die begrafnis as 'n kerklike aangeleentheid gesien. Die begrafnisdiens, sê hy, moet die gelowiges se geloof versterk en hulle tot ware ootmoed bring. Die klem moet nie gelê word op die dooie nie, maar op die opstanding wat in die prediking, die gebed en die lied tot uitdrukking moet kom. Die begrafnis moet deur die kerk plaasvind, want die gestorwenes is die gemeente se broers en susters in die geloof (Davies 1972: 102). As gevolg van sy stryd teen die Roomse gebruike, het Luther self nie so ver gekom om die begrafnis 'n kerklike aangeleentheid te maak nie. Hierdie stap sou eers in die sestiende eeu kom.

Gedurende die sestiende eeu het die begrafnisdiens in Lutherse kerke 'n sterk kerklike karakter gedra. Behalwe die gebed en die sang het die preek in hierdie tyd algemeen voorgekom. Die prediking was Bybels-Christologies.

In die sewentiende eeu het daar in die Lutherse kerk weer verandering gekom:

... a strong personal element was added, among other things by the inclusion of a curriculum vitae; at the same time, funeral sermons took on a learned tone, used allegory and often occupied an intolerable amount of time. A eulogy of the dead person took precedence over what were originally the main themes of funeral sermons (the proclamation of the last things, preparation for a happy death) ( $E$ Winkler). At the time of the Enlightenment the biblical orientation of the funeral sermon disappeared still more; at its centre stood the life of the dead person and the parting from him, both presented in the baroque and sentimental style of the time. In many places there was no funeral sermon at all. This was connected with an extremely strange development. Silent 'interments', once provided for suicides, notorious sinners, etc. took the place of public funerals. It became the custom to inter the dead at a late hour of the evening or at midnight, by torchlight, with only family and friends present, and usually without any participation by the pastor. The place of the funeral sermon was taken by the 'eulogy' of a friend at the graveside. The funeral service of the congregation in many cases, particularly in towns, became a family gathering (Davies 1972: 103-104). 


\subsubsection{Calvinistiese kerke}

In die Calvinistiese kerke was daar groot verset teen die Rooms-Katolieke gebruike by begrafnisdienste. Uit reaksie daarteen is daar by die meeste begrafnisse geen kerklike diens gehou nie (Golterman 1951: 161). Hierdie toestand het in Straatsburg tot ten minste 1533 geheers. Tydens die sinode van 1533 is besluit dat na analogie van die vroeë Christelike kerk die predikant tog by die begrafnis teenwoordig behoort te wees. Daar is egter eers teen 1537 'n liturgiese orde opgestel vir 'n begrafnisdiens. Dit het uit die volgende elemente bestaan: Skriflesing, vermaning, gebed en dankoffer. Hierdie orde is waarskynlik deur Bucer gebruik. Calvyn het aan die stadsowerheid van Geneve gehoor gegee. Hulle het net soos die van Zürich, Bern en Basel bepaal dat 'n begrafnis sonder die medewerking van 'n predikant moet geskied. In Straatsburg het Calvyn egter die begrafnis hanteer as 'n kerklike aangeleentheid (Pont 1984: 113). $\mathrm{Na}$ aanleiding van 'n brief aan Farel skryf Davies die volgende begrafnisgebruike aan Calvyn toe:

The corpse shall be carried by trusty men from the city to the cemetery. The whole church shall follow with great modesty, the pastor or other minister leading. When it is come to the place where the body is to be placed in the ground, a brief address concerning death and the resurrection of the dead is given, with commendation of the deceased, if he has any virtues from which to edify the church. Prayer shall be made for the church that as God gives us this transient life so we may pass through death into his Kingdom, and that he will raise all through Christ at the last day to immortality. The people shall be dismissed with an admonition that they give an offering for the relief of the poor (Davies 1972: 107).

Met die oog op die vermyding van die Roomse bygeloof en bygelowige gebruike is die begrafnis in Nederland ook nie as 'n gemeentelike of kerklike saak beskou nie. 'Die Sinode, gehou te Vigne in 1564, het juis om die Roomse bygeloof en bygelowige gebruike te vermy, selfs bepaal dat by begrafnisse nie gebid of gepreek mag word nie' (Pont 1984: 113). Die Sinode van Dordrecht 1578 het hom ook teen die hou van eredienste by die begrafnis uitgespreek.

Ouermidts het ghebruyck der Lyckpredicken seer sorgherlick is, soo ghevoelen wy, datse in de plaetsen daer se niet en syn, niet en behooren inghevoert te werden. Maar daerse gehwoonlick syn ghehouden te worden ende het ghetal der Dienaeren ghenoeghsaem 
is, de welcke metgaders den Ouderlinghen de selvighe oordeelen niet onnut te syn, sullense gheduldet worden, ter tyt toe datse ter bequaemer gheleghenheyt sonder erghernisse sullen mogen affghesett worden. Nochtans met deser waerschouwinge datse meer een forme hebben van een onghepremediteerde vermaninghe dan van eene predicatie de welcke van den ghebeden beghonnen ende met danck segghinge ghesloten wordt. Datmen oock in den der affghestoruener seluigen loff niet en vercondighe. Het sal oock der Dienaren Ampt syn sorghe te draghen dat het ghebruyck der clocken de welcke in den Pausdom soo int verscheyden als int begrauen der menschen gheluyt worden, wegh ghenomen werde' (Rutgers 1889: 248-249; aangehaal in Pont 1984: 114).

Die Sinodes na 1578 het feitlik gelykluidende besluite oor die begrafnisdienste geneem.

Daarmee is ' $n$ vaste reël in die Nederlandse kerk ingevoer wat met verloop van die tyd 'n algemene gebruik geword het. Selfs met die verandering van die kerklike orde in 1816 het daar, wat die begrafnis betref, geen verandering gekom nie. Dit is opvallend dat onder die besondere pligte van die predikant, die hou van begrafnisdienste nie genoem word nie (C Hooijer 1846 : 113) en dat die begrafnisdiens ook nie genoem word onder die 'kerklijke vierdagen en plegtighede' nie. Dan is dit al 'n gewoonte dat die begrafnisdiens 'n suiwer familieaangeleentheid is. Hoewel die verbod op die predikant se deelname aan so ' $n$ begrafnisdiens nie meer toegepas word nie, is dit duidelik dat die begrafnis buite die gereelde orde en ritme van die lewe van die gemeente val. Hier was daar ook nie 'n onderskeid wat getref is tussen 'n begrafnisdiens en 'n teraardebestelling nie. Beide was sake van die familie' (Pont 1984: 116).

Sedert die tweede helfte van die negentiende eeu het teoloë al hoe meer besef dat die Reformatore die begrafnis net as ' $n$ familie-aangeleentheid hanteer het om van die 'Roomse bygeloof' ontslae te raak en nie so seer om prinsipiële redes nie. Die begrafnis is onder andere deur WF de Gaag Fortman, Haendler, Veleman, Golterman, Van der Leeuw en van Oosterzee beskryf as 'n kerklike aangeleentheid waartydens erediens behoort gehou te word ( kyk Barnard 1976: 78; Wagenaar 1964: 54). 
Die vroeëre gebruik van Nederland om die begrafnis in die hande van die familie te laat, is met die volksplanting na Suid-Afrika oorgedra.

Sover die geskiedenis nagegaan kan word, was dit altyd so dat die familie die taak op hulle geneem het om 'n oorledene te begrawe. Die samekoms van die familie en vriende voor die teraardebestelling is nog tot in die vyftigerjare van hierdie eeu, normaalweg deur 'n koster voorgegaan. Hy was gewoonlik een van die ouderlinge van die gemeente. In die twintiger- en dertigerjare was dit ook die uitsondering dat 'n predikant die begrafnisverrigtinge gelei het. Daarby was dit op die platteland die uitsondering dat die familiesamekoms in 'n kerkgebou gehou is. Gewoonlik is of die sterfhuis, of as dit nodig was, op die plaas, skuur of 'n ander groter ruimte gebruik vir die samekoms voorafgaande aan die teraardebestelling (Pont 1984: 116).

Opsommend kan vanuit die historiese gegewens gesê word dat die begrafnisdiens in die vroeë kerkgeskiedenis as 'n kerklike aangeleentheid beskou is. Die Roomse bygeloof en seremonies het egter daartoe bygedra dat die Reformatore die begrafnisdiens uit die sfeer van die kerklike bediening geweer het. Sedert die negentiende eeu is die begrafnisdiens weer allerweë beskou as 'n kerklike aangeleentheid.

\section{JONGSTE STANDPUNTE OOR DIE BEGRAFNISDIENS}

De Wet $(1965: 47,48)$ het sterk gepleit dat die begrafnisdiens as 'n kerklike aangeleentheid hanteer moet word. Hy wou dat 'n erediens met al die elemente van 'n gewone erediens behou word:

Hierdie gebeurtenisse naamlik die huwelik en die begrafnisdienste moet openbare byeenkomste van die gemeente gemaak word wat die karakter dra van 'n gesprek tussen God en sy gemeente. Die Woord van God in sy gestaltes van wet, Skrif en prediking moet resloos erns mee gemaak word. Ook wat betref die inhoud van die prediking moet daar besondere aandag gegee word, want by hierdie geleenthede kom daar in die reël heelwat buitekerklikes onder die prediking. En al kan goedversorgde prediking die Gees van God nie afdwing nie, dan kan slordige en onversorgde prediking die Gees wel in sy gang hinder. Die antwoord van die gemeente as skuld- en geloofsbelydenis, sang en gebed moet ook tot sy reg kom. Die soliste en operasterre sal die 
arena moet verlaat. Dit sal net kan gebeur as die gemeente weer eens hulle deelhebbe aan die erediens belewe. Hoe ongewoon en vreemd dit ook mag klink: die offergawe sal ook by hierdie geleenthede gebring moet word.

Wagenaar (1964: 10) sien ook die begrafnis as 'n kerklike aangeleentheid. Hy vra die vraag: Wat doen die kerk as hy 'n begrafnis lei? Hy antwoord self soos volg:

- Die kerk bewys die laaste eer aan die oorledene

Op grond van die feit dat God op 'n besondere manier deur die lewe van die ontslapene Sy werk in die kerk en die wêreld laat doen het, kom die gemeente om God daarvoor te dank.

- Die kerk neem afskeid van die oorledene

Die ontslapene is feitelik weggeneem. Hierdie feit vra egter dat wij hem ook innerlijk, psychisch loslaten' (Wagenaar 1964: 10). Hierdie daad sê dat dit die werk van die familie is, maar ook van die gemeente. Die gemeente se werk is in die besonder om die familie in hierdie proses van loslating pastoraal te begelei.

- Die kerk bely die sorg van God ten opsigte van die corledene Deur die begrafnis word dit duidelik dat die gestorwene losgelaat is van die sorg van die familie en gemeente. Positief word hy nou deur die begrafnis toevertrou aan die sorg van God.

- Die kerk vertroos die familie

Tydens die begrafnis word die familie getroos vanuit die Woord van God.

Die besondere funksies waarna Wagenaar verwys, is feitlikhede wat gebeur tydens die begrafnis. In die gebed word God gewoonlik gedank vir die werk wat Hy deur die gestorwene gedoen het. God word ook gedank vir die besondere sorg in Jesus Christus omdat elkeen wat in Hom glo, deel het aan die ewige lewe. Beide hierdie aspekte kan ook in die prediking tydens die begrafnis na vore kom. In funksie is die begrafnis ook die besondere geleentheid waar die familie van die gestorwene 'losgemaak' word en waar mense vir die enigste keer die geleentheid kry om teenwoordig te wees by 'n geleentheid waar die gestorwene se heengaan hulle bymekaar gebring het. Op grond hiervan word heeltemal tereg gepraat van die laaste eer wat aan die persoon bewys word. 
Wanneer egter gevra word na die kerk se taak in hierdie verband sal ons moet volstaan met die laaste stelling van Wagenaar. Die Kerk sien sy taak by die begrafnis as pastorale begeleiding van die familie en die teenwoordiges. Dit beteken: vir die kerk is dit die geleentheid om aan hierdie mense die Woord te verkondig, vir hulle te bid en hulle barmhartig te ondersteun.

Dit was veral AD Pont wat wydlopende kritiek teen die besluit van die Algemene Kerkvergadering van die Nederduitsch Hervormde kerk van Afrika van 1976, soos in die Diensboek verwoord, uitgespreek het. 'Hieruit blyk dat die besluite van die Algemene Kerkvergadering van 1976, met betrekking tot die begrafnisdiens en soos saamgevat in die Diensboek, in die gemeente geen neerslag of navolging gevind het nie' (Pont 1984:112). Pont se konklusie is: 'Die begrafnis is nie 'n gemeentelike aangeleentheid nie, maar primêr 'n saak van die familie en die vriende van die familie' (Pont 1984:117). Opsommend is Pont se kritiek die volgende:

* Die begrafnisdiens word nie deur die gemeentes in praktyk as 'n buitengewone erediens beskou nie. Baie elemente van die erediens soos die lees van die wet, die lees van die geloofsbelydenis en die deurkollekte kom nie in die begrafnisdiens voor nie.

* Daar is nie ouderlinge om opsig te hou, teenwoordig nie.

* Die kerkraad bepaal nie hierdie erediens soos die kerkwet voorskryf ten opsigte van alle eredienste nie (Bepaling 5:16).

Pont se oordeel dat die begrafnisdiens nie as 'n buitegewone erediens in die praktyk gesien word nie, is nie reg nie. Vir die gewone kerkpubliek het die begrafnis 'n baie sterk kerklike karakter. Na die afsterwe is dit gewoonlik die predikant wat eerste in kennis gestel word. Die reëlings vir die begrafnis word in 'n baie groot mate in sy hande gelaat. Die familie aanvaar dit as vanselfsprekend dat daar 'n diens in die kerk sal wees en dat die predikant by die graf die leiding sal neem. In breë trekke is die diens in die kerk 'n erediens. Die kernelemente van prediking, gebed en sang is teenwoordig. Die elemente wat ontbreek, naamlik 'Wet, geloofbelydenis, skuldbelydenis en genadeverkondiging word in die gebed of sang ingesluit' (Diensboek 1977: 24). Die teenwoordigheid van 'n ouderling is volgens Pont self nie altyd so noodsaaklik nie. 'Die gewoontereg eis dat ouderlinge teenwoordig moet wees om 'n wettige godsdiensoefening te kan hou. Indien egter na die oorsprong van hierdie reël gekyk word, word dit 'n interessante vraag of dit vandag nog as 'n absolute eis gehandhaaf hoef te word, veral in die lig van die feit dat die predikant die kerklike proponentsformule onderteken het en die lidmate ook in staat is om die kwaliteit 
van die prediking te beoordeel' (Pont 1984: 117-118).

As die kerkwet van die Nederduitsch Hervormde Kerk van Afrika in Bepaling 5:1b, waar gesê word dat die kerkraad die plek en die tyd van die erediens bepaal, nie melding maak van die begrafnisdiens nie, is dit seker omdat reeds aanvaar is dat die begrafnisdiens ' $n$ erediens is en daarvan nie afsonderlik melding gemaak hoef te word nie.

Vanaf die veertigerjare het dit in Suid-Afrika al hoe meer gebruik geword om die begrafnisdiens in 'n kerkgebou te hou. Die diens in die kerk word deur die teraardebestelling gevolg wat gewoonlik deur die predikant waargeneem word.

Die standpunt van die Nederduitse Gereformeerde Kerk word deur Barnard soos volg gestel:

Dit is duidelik dat die begrafnis in die eerste plek 'n aangeleentheid van die familie is, maar dis ook 'n aangeleentheid van die kerk. Die gemeente wat een van sy lidmate deur die dood verloor het, moet sorg dra dat die naasbestaandes deur die verkondiging van die Woord van God getroos word, dat hulle die betekenis van die dood en die opstanding van die dode in Skriftuurlike lig sien en dat hulle in die voorbidding van die gemeente aan die Here opgedra word' (Barnard 1976: 78).

Vir hierdie kerklik-familie aangeleentheid word 'n bepaalde erediensorde voorgeskryf wat prediking en ander elemente van die erediens bevat. Dit word gevolg deur 'n kort voorgeskrewe orde by die graf.

Die Gereformeerde Kerke se besluit oor die begrafnisdiens is soos volg: 'Aangesien 'n begrafnis in hoofsaak 'n familie-aangeleentheid is en dus nie ' $n$ erediens is nie, volg die voorganger 'n vrye orde, waartydens hy uit die Woord van God trooswoorde tot die naasbestaandes rig sonder egter om 'n 'lykpredikasie' te hou' (Sinodebesluit 1986: 423). Nieteenstaande die besluit van die Sinode is dit algemene praktyk in die Gereformeerde Kerke dat die begrafnis as 'n kerklikfamilie aangeleentheid hanteer word, dat daar 'n erediens in die kerk gehou word met ten minste 'n preek, gebed en sang en dat dit gevolg word deur 'n teraardebestelling wat deur die predikant gelei word.

Die Nederduitsch Hervormde Kerk van Afrika sien die begrafnis ook as 'n kerklik-familie aangeleentheid. Die diens in die kerk en die by die graf word onderskei. Die diens in die kerk word beskou as 'n kerklike aangeleentheid en die by die graf as ' $n$ familie-aangeleentheid. 'Die kerk moet duidelik onderskei tussen die begrafnisdiens wat 'n vertroostende verkondigingstaak van die kerk is aan die 
agtergeblewenes en die teraardebestelling wat die taak en voorreg is van die agtergeblewenes. Die teraardebestelling word in die Bybel duidelik geteken as taak en voorreg van die familie (Gen 23: 6, 11, 15; 47: 30; 39: 29; Matt 8: 21; 27: 57-61; Joh 11: 34). Die kerk en sy ampsdraers is alleen betrokke by die teraardebestelling as hulle daartoe deur die familie gevra word. Aangesien die predikant daarvoor toegerus is, kan hy aanbied om die verrigtinge by die graf namens die familie te lei of hulle met die reëlings daaraan verbonde, behulpsaam te wees. Die begrafnisdiens is net soos enige ander diens in die kerk erediens en moet daarom al die kenmerke en elemente van 'n gewone erediens vertoon. Dit vind plaas met al die elemente net soos die Sondagerediens. Net soos in die geval van die huweliksbevestiging kan wet, geloofsbelydenis, skuldbelydenis en genadeverkondiging in die gebed of in die sang opgeneem word' (Diensboek 1977: 32).

In 1964 bet die kerklike begrafnis met 'n preek ook feitlik algemene gebruik van die Hervormde Kerk in Nederland geword:

In onze eeuw is dit een algemene gewoonte geworden. Soms in de vorm van een dubbele verkondiging: eerst in sterfhuis, herberg of aula, daarna nog een keer bij het graf. In de meeste gemeenten echter enkelvoudig: niet bij het graf wegens minder gunstige omstandigheden, maar voor de gang naar het kerkhof. Bij het graf spreekt de predikant meestal alleen de begrafenisformule uit en bidt het 'Onze Vader' (Wagenaar 1964: 54).

Davies (1972: 108) oordeel ook dat die kerklike begrafnisdiens in die twintigste eeu in reformatoriese kerke feitlik algemeen geword het.

An examination of modern Reformed burial rites in Scotland, England, Ireland, Wales, Canada, Australia and South Africa reveals a common structure and content, and that they all been much influenced by the Euchologion and BCP. All provide for two services, one in church or home, and the other at the graveside. While there are variations in details, the general order of the former is scripture sentences, invocation, psalm, scripture readings, address, prayers of adoration, confession, thanksgiving, supplication, intercession and commemoration of saints, hymn and benediction. At the graveside the order is scripture sentences, committal, prayers and benediction. 


\section{EVALUASIE VAN GEGEWENS}

Uit die voorafgaande is dit duidelik dat die Bybel nie sonder meer die vraag beantwoord of die begrafnis ' $n$ kerklik of 'n familie-aangeleentheid is nie. Uit die Bybelse gegewens kan ons egter aflei dat die begrafnis 'n familie-aangeleentheid is vanweë die besondere betrokkenheid van die familie daarby. Aangesien die grense van kerk en volk in die Ou-Testament feitlik saamgeval het, was die begrafnis net soveel 'n kerklike aangeleentheid. Die kerk se roeping om die evangelie aan mense in nood te verkondig en om hulle barmhartig te ondersteun, maak die begrafnis sonder enige twyfel 'n saak waarby die kerk ten volle betrokke is.

Uit die vroeëre en die latere geskiedenis van die kerk kan ons die afleiding maak dat die begrafnis die grootste gedeelte van die tyd as 'n kerklike aangeleentheid beskou is. Prinspieel het die meeste Reformatore die begrafnis ook as ' $n$ kerklike aangeleentheid beskou. Hulle het dit slegs in die praktyk, as gevolg van die 'Roomse dwaalleer', as kerklike aktiwiteit afgewys.

Dat hierdie geleentheid nieteenstaande die kerk se betrokkenheid, nogtans 'n sterk familie-aangeleentheid is, sal niemand egter ontken nie. Kerklike betrokkenheid en familiebetrokkenheid loop hier deurmekaar en inmekaar. In plaas van om die twee te skei, sal dit miskien beter wees om van die begrafnis in die geheel as 'n kerklik-familie-aangeleentheid te praat. In die praktyk beteken dit dat die kerk die breë riglyne neerlê, soos reeds gedoen in die vorige Diensboek, en die familie uiting aan hulle wense binne die grense van hierdie breë riglyne gee. As die begrafnis slegs ' $n$ familie-aangeleentheid is, sou dit beteken dat die familie oor alles besluit en die begrafnis net soos hulle wil, sonder enige inspraak van die kerk, laat plaasvind.

\section{DIE PRAKTIESE BETROKKENHEID VAN DIE KERK BY DIE BEGRAF- NISDIENS}

In die lig van die voorafgaande sal die volgende vrae beantwoord moet word: Hoe sal die kerklike verkondiging tydens en rondom die begrafnis daar moet uitsien? Watter liturgiese orde en ander gebruike sal gevolg kan word en waaruit sal die kerk se barmhartigheidsdiens op hierdie stadium moet bestaan?

Hierdie verkondiging sal uit die aard van die saak uit pastorale gesprekke en wat daarmee saamgaan, bestaan. Moet die kerk daarby volstaan en die res dan in die familie se hande laat, of moet die kerk nog 'n erediens ook hou? Die feit dat daar gewoonlik 'n baie groot klomp mense betrokke is by die dood van 'n lidmaat, bring noodwendig mee dat 'n geleentheid geskep moet word waar die kerk tot hierdie groot groep mense kan spreek. Kragtens sy opdrag kan die kerk nie anders as 
om die Woord aan hierdie mense te verkondig nie. Hierdie verkondiging vind in die besonder tydens die begrafniserediens plaas.

Dieselfde beginsels wat vir enige ander preek geld, sal hier ook geld. Dit sal Woordverkondiging moet wees. Dit beteken die Skrif moet verklaar en toegepas word vir die mense wat daar teenwoordig is. 'Das Amt des Wortes bei der B. ist Predigt, d.h. auftragsgemäbe, textgebundene Verkündigung, zum sachgerechten Dienst am besonderen Fall (nicht primär am Toten) und an den von ihm betroffenen Menschen' (Mezer 1975: 105).

Die Skrif wat by hierdie geleentheid verklaar word, is dieselfde Skrif wat elke Sondag in die prediking gebruik word en dieselfde Skrif wat in die week tydens huisbesoek gebruik word. Die mense wat egter by die begrafnis teenwoordig is, is nie sonder meer dieselfde mense wat Sondag in die erediens teenwoordig is nie. In die begrafnisdiens is gewoonlik gelowiges en ongelowiges teenwoordig. Hier is mense teenwoordig van jou eie kerk maar ook van ander kerke. Al die mense wat teenwoordig is, is op een of ander wyse aan die gestorwene verbind. Dit bring mee dat elkeen op een of ander wyse hartseer is oor die persoon wat gesterf het.

In hierdie besondere situasie moet die Woord inspreek. Met hierdie geleentheid wil die kerk die mense wat teenwoordig is, vertroos, bemoedig en vermaan. Die troos wat die Kerk gee, is in Jesus Christus deur die Woord. Hierdie troos en bemoediging bevat myns insiens twee aspekte: die troos dat God deur Jesus Christus die dood oorwin het, en dat op grond van God se liefde in Jesus Christus deur die Heilige Gees, God se kinders nie soos wese agtergelaat word nie, maar dat Hy self by en met hulle is. Die vermaning aan die ander kant bevat ook hierdie selfde dubbele aspek: vir die wat nie in Christus glo nie, wag die oordeel van God, en vir die wat nie in Christus glo en op God hulle vertroue stel nie, is die pad vorentoe 'n swaar en eensame pad. Op twee groot gevare sal deurgaans gelet moet word: Enersyds die gevaar dat God se genade nie goedkoop gemaak word en die indruk gelaat word dat alle mense gered sal word nie; andersyds die gevaar dat die indruk gelaat word dat God se genade deur goeie werke verdien kan word.

In hoeverre gaan dit in hierdie besondere verkondiging om die gestorwene? Op grond van die kerk se besondere funksie ten opsigte van die dooie is Wagenaar van oordeel dat dit by die begrafnis om die lewende en die dooie gaan. 'De Kerk begraaft haar dode, en verkondigt het Evangelie aan de levende' (Wagenaar 1964: 12). Hy oordeel daarom:

De verkondiging heeft met het concrete geval ernst te maken. Anders maakt zij ook geen ernst met het Evangelie en is zij ook niet troostend. Dan gaat zij immers aan de situatie voorbij. Het Evangelie 
wordt een algemene waarheid, die 'naar aanleiding van' het sterfgeval geillustreerd wordt. Daarom dient, indien mogelijk, het leven van deze gestorvene in de verkondiging verdisconteerd te worden. Wij nemen een mens als schepsel Gods niet serieus, als onze begrafenispreken verwisselbaar zijn. Zij dienen het Evangelie toe te spitsen op hen, die ter wille van deze dode bijeengekomen zijn. Ook wanneer wij volstrekt over de dode zwijgen, spreken wij over hem door ons zwijgen wellicht welsprekender dan onze woorden hadden kunnen doen. Het leven van de dode blijft ergens thema, ook als wij in een zeker purisme zeggen, dat wij uitsluitend met de levenden te maken hebben, aan wie wij het Evangelie mogen verkondigen' (Wagenaar 1964: 12).

In breë trekke stem ons saam met Wagenaar. Hier moet egter hoogstens volstaan word met' $n$ enkele opmerking en nie 'n breë beskrywing van die oorledene se lewe nie. Die prediker sal veral versigtig moet wees om nie self te besluit of die gestorwene salig is of nie. Die meeste wat miskien gesê kan word, is: 'Aangesien die oorledene geglo het in Jesus Christus, glo ons hy het ook deel aan die ewige lewe wat Jesus Christus vir sy kinders berei het .... Aangesien julle in die drie-enige God glo, daarom glo ons sal Hy ook met julle wees in die swaar dae wat voorle'. As die oorledene egter nie 'n gelowige was nie, kan die geleentheid benut word om die teenwoordiges op te roep tot geloof in Jesus Christus. As die familie ongelowiges is, kan die geleentheid ook benut word om aan hulle te verkondig dat daar vir 'n mens slegs troos, krag en hulp by God is as jy in Hom glo.

Aangesien die familie reeds 'n baie moeilike tyd agter die rug het, sal dit miskien goed wees om die prediking so kort as moontlik te hou.

Beoefenaars van die Liturgiek soos Van der Leeuw (1946: 223-224), Golterman (1951: 162), Wagenaar (1964: 58) en Barnard (1976: 79-80) skryf almal bepaalde liturgiese ordes vir die begrafnisdiens in die kerk en by die graf voor. In die meeste van die liturgiese ordes kom al die elemente van die gewone erediens voor, behalwe wetlesing en skuldbelydens.

Die Nederduitse Gereformeerde Kerk skryf 'n liturgiese orde vir die begrafniserediens voor wat die meeste van die elemente van die gewone erediens bevat (Barnard 1976: 79-80). Hoewel die Gereformeerde Kerke in Suid-Afrika nie 'n vaste liturgie vir die begrafnisdiens voorskryf nie, word hulle gewone diensorde oor die algemeen gevolg, met weglating van skuldbelydenis, genadeverkondiging, wetlesing, geloofsbelydenis en insameling van offergawes (Sinodebesluite 1986: 424). 
Die Nederduisch Hervormde Kerk van Afrika skryf in sy Diensboek van 1977 vir die begrafnisdiens dieselfde liturgiese ordes as vir die gewone erediens voor. Daar word egter gesê dat by huweliksbevestigings en begrafnisse wet, geloofsbelydenis, skuldbelydenis en genadeverkondiging in die gebed of in die sang opgeneem kan word (Diensboek 1977: 32). In die Diensboek van 1987 word nie 'n beskrywing van die buitegewone eredienste gegee nie, maar slegs twee liturgiese ordes met die basiese elemente van Skriflesing, prediking, gebed en sang (Diensboek 1987: 29-30).

As die verskillende genoemde liturgiese ordes met mekaar vergelyk word, is daar groot ooreenstemming. Die uitspreek van die votum en seën by die graf en die kerk is egter 'n onnodige duplisering. Aangesien by die graf ook gebid word, is dit seker nie nodig dat daar meer as een keer in die kerk gebid hoef te word nie. Dit lyk besonder sinvol om die geloofbelydenis tydens 'n begrafnis te lees of te laat sing. Dit kan in die kerk of by die graf plaasvind. Die lees van Psalm 103 soos voorgestel deur Van der Leeuw sal veral kan dien as 'n besonder geskikte Skrifgedeelte om by die graf te lees. Psalm 103 kan ook gelees word as genadeverkondiging tydens die erediens. Die besondere aard van die begrafnisdiens bring mee dat die deurkollekte nie gepas is nie. Hier kan volstaan word deur hoogstens te sorg dat daar permanente geldbussies by die kerk is, sodat as iemand die behoefte het om geld in te gooi, hy dit wel kan doen.

Dit het reeds 'n vaste gebruik by ons geword dat 'n begrafnisbrief gelees en bedankings op een of ander stadium van die begrafnis gedoen word. Die begrafnisbrief het seker sy oorsprong by die nekrologie van die ontslapene wat in die verlede voorgelees is. In sy Diensboek laat die Nederduitse Gereformeerde Kerk wel ruimte vir 'n nekrologie.

$\mathrm{Na}$ die seënbede kan 'n nekrologie en die name van die draers voorgelees word alvorens die lykstoet na die begraafplaas vertrek. By die opstel van die nekrologie moet met die grootste versigtigheid gehandel word. Die Woordverkondiging laat tog genoeg ruimte om die besondere fasette van Gods genadewerk in die lewe van die oorledene te onderstreep sodat 'n afsonderlike nekrologie oorbodig is. Indien dit tog gedoen word, moet die leraar dit self opstel en sorg dra dat dit sober, kort en feitelik korrek is (Barnard 1976: 80).

Die Diensboek van die Nederduitsch Hervormde Kerk van Afrika bepaal: 'Na die afsluiting van die diens met die seën, word die begrafnisbrief met die name van die draers gelees. Laasgenoemde lei die familie uit die kerk uit' (Diensboek 1977: 32). 
Dit is ook baie sinvol om die begrafnisbrief voor die uitspreek van die votum te lees. Dit vestig die teenwoordiges se aandag op 'n besondere wyse op dit wat gaan plaasvind. In hierdie geval word die draers se name eers aan die einde van die diens gelees. Na die uitspreek van die seên kan 'n kort woord van simpatie namens die kerkraad gespreek word en kan een van die familie die bedankings doen.

Aangesien 'men niet voor den doode, maar voor de levenden spreekt en bidt' word die kis in die lykswa gelaat (Achelis 1906: 149). Die teenwoordigheid van die $k i s$ in die kerk lei dikwels daartoe dat slegs die aanskoue daarvan die troosteloosheid van die familie vergroot. Aangesien die kis in die lykswa gelaat word, is dit nie nodig dat die draers in die kerk na vore hoef te kom om die stoet uit die kerk uit te lei nie.

By die graf is dit gebruik dat ' $n$ gepaste formule gespreek word nadat die kis neergelaat is.

Daar dit die almagtige God behaag het om ons dierbare, tans gestorwe broeder/suster, $\mathrm{N}$, tot Hom te neem;

daarom vertrou ons sy/haar liggaam aan die aarde toe, aarde tot aarde, as tot as, stof tot stof;

in die vaste en sekere hoop van die opstanding tot die ewige lewe deur ons Here Jesus Christus, wat ons vernederde liggaam aan sy verheerlikte liggaam gelyk sal maak en ons tot Hom sal neem in ewigheid.

Amen (Diensboek 1977: 90).

Hierdie formule het, volgens Wagenaar, sy oorsprong in die Engelse hervormde kerke en is 'n vertaling van die formule soos dit opgeteken is in The Book of Common Prayer (Wagenaar 1964: 59). 'Het werpen van een schep aarde op het graf is een survival uit heidense tijden'(Wagenaar 1964: 21). Aangesien dit geen besondere funksie vervul nie, moet dit miskien liewer gelaat word. Gewoonlik is die smart rondom die graf baie groot en is dit gevolglik gewens om hier slegs te laat sing indien daar mense teenwoordig is wat in hierdie verband goeie leiding kan neem.

Opsommend lyk die volgende 'n sinvolle liturgie te wees vir 'n begrafnisdiens: 
By die kerk:

Votum en seĕn

Lofsang

Gebed

Skriflesing

Prediking

Geloofsbelydenis (Die gemeente sing as geloofbelydenis Gesang 245: 1, 8, 9 \& 10) Seën.

Na die diens in die kerk:

Kort woord van simpatie namens die kerkraad

Bedankings

Begrafnisbrief met 'n baie kort nekrologie.

By die graf:

Terwyl die kis sak, Psalm 103 of die geloofbelydenis

Begrafnisformule

Gebed.

Die barmhartigheidsdiens van die kerk sal rondom die afsterwe van die persoon oor 'n baie breë linie strek. Dit sal bestaan uit geestelike en materiële steun voor tydens en na die begrafnis ten opsigte van elkeen wat op 'n besondere wyse deur die afsterwe van die betrokkene geraak is. Die kerk sal veral besondere barmhartigheid aan die familie bewys as die predikant die teraardebestelling vir hulle waarneem.

\section{Literatuurverwysings}

ACHELIS, E 1906. Praktisch theologie: Voor Nederland bewerkt door LW Barkhuizen van de Brink. Kemink \& Zoon.

BARNARD, AC 1976. Die erediens: 'n Handleiding by die Kerkboek. Kaapstad: NG Kerk Uitgewers.

DAVIES, JG 1972. A dictionary of liturgy and worship. London: SCM Press.

DE VAUX, R 1961. Hoe het oude Israel leefde: De instellingen van het Oude Testament, I.Rórmond-maaseik: JJ Romen \& Zonen uitgevers. 
DE WET, JI 1965. Liturgiek I. Ongepubliseerde diktaatlesings. Universiteit van Pretoria.

DIENSBOEK: VIR DIE GEBRUIK IN DIE NEDERDUITSCH HER VORMDE KERK VAN AFRIKA 1977. Pretoria: Weeshuispers.

DIENSBOEK: NEDERDUITSCH HERVORMDE KERK VAN AFRIKA 1987. Pretoria: Weeshuispers.

GOLTERMAN, WF 1951. Liturgiek. Haarlem: De Erven F Bohn.

HOENDERDAAL, GJ 1977. Riskant Spel: Liturgie in een geseculariseerde wêreld. Gravenhage: Boekencentrum.

KERKWET EN BEPALINGS VAN DIE NEDERDUITSCH HERVORMDE KERK VAN AFRIKA 1951. Soos gewysig tot en met die 61ste Algemene Kerkvergadering 1986. Pretoria: NHW Pers.

KERSTEN, GH 1961. Kerklijk handboekje: Opnieuw uitgegeven op last van de Generale Synode der Gereformeerde gemeenten in Nederland. Utrecht: N.V. Drukkerij-Uitgeverij 'De Banier'.

MEZER, B 1975. Gestalttung in Praktisch Theologisches Handbuch. Hamburg: Furche-Verlag.

PONT, AD 1984. Rondom die begrafnisdiens. HTS 40/1, 119-129.

ROWELL, R 1977. The liturgy of christian burial. London: Clowes.

VAN DER LEEUW, G 1964. Liturgiek Nijkerk: GF Callenbach.

WAGENAAR, LG 1964. Die kerkelijke begrafenis. s' Gravenhage: Boekencentrum. 